\title{
Bioactive Peptides by in vitro Digestion of Germinated Bean Cotyledons Extrudates
}

\author{
Lidia López-Barrios ${ }^{1}$, Erick Heredia-Olea ${ }^{1}$, Daniel Guajardo-Flores ${ }^{1}$, Esther Pérez-Carrillo ${ }^{1} \&$ Janet A Gutiérrez \\ Uribe $^{1}$ \\ ${ }^{1}$ Tecnológico de Monterrey, Centro de Biotecnología FEMSA, Monterrey, Nuevo León, México \\ Correspondence: Erick Heredia Olea, Tecnológico de Monterrey, Centro de Biotecnología FEMSA, Av. Eugenio \\ Garza Sada 2501 Sur, Monterrey, Nuevo León, C.P. 64849, México. E-mail: erickho@itesm.mx
}

Received: November 3, 2017

Accepted: November 24, 2017 Online Published: January 6, 2017

doi:10.5539/jfr.v7n1p76

URL: https://doi.org/10.5539/jfr.v7n1p76

\begin{abstract}
Germinated black bean cotyledons were extruded at two different screw speeds (350 or $400 \mathrm{rpm}$ ). Extrudates were digested with pepsin and pancreatin to evaluate the antioxidant and anti-inflammatory activities of hydrolysates collected at $0,60,90,120$ and, $180 \mathrm{~min}$. Soluble protein recovered before the enzymatic digestion of extrudates obtained at $350 \mathrm{rpm}$ (E1), or $400 \mathrm{rpm}$ (E2) showed the highest antioxidant (AOX) capacity, with 2,790 or $2,335 \mu \mathrm{mol}$ eq Trolox/g, respectively and the best nitrogen oxide inhibitory. Even though extrudates presented different peptides profiles, the enzymatic digestion of the storage proteins released similar peptides. RLL and YAL were among the identified peptides obtained after $180 \mathrm{~min}$ of enzymatic digestion. Extrusion can be a useful process to produce novel functional ingredients from legume proteins for the food industry.
\end{abstract}

Keywords: anti-inflammatory activity, antioxidant activity, black beans, extrusion, legumin, peptides, protein hydrolysates

\section{Introduction}

Diverse studies had shown the health benefits of legumes in daily diet like reduction of atherosclerosis, diabetes, hypertension, osteoporosis, cancer, etc. The high protein content, around $18-32 \%$, and good amino acid profile give to legumes the potential to be the best alternative to eradicate diseases produced caused by inadequate nutrition. However, legumes had a lack of S-c containing amino acids (cysteine, cystine, and methionine), for this reason the legumes need to be complemented with cereals to compensate the lack of amino acids (Iqbal et al., 2006). Despite this amino acid deficiency, legumes had comparable amino acid profile ( 80-90) compared with daily products as milk, cheese, eggs, fish, or meat (Sosulski \& Imafidon 1990). Common bean (Phaseolus vulgaris L.) is a highly consumed legume worldwide that contains bioactive compounds including peptides. Activities described for common bean bioactive peptides (BP) include antioxidant, antihypertensive, anti-inflammatory, anticancer, antifungal, and antidiabetic (Luna-Vital et al., 2014; Rocha et al., 2015, Marques et al., 2015). The peptides can be obtained by enzymatic hydrolysis, fermentation, or food processes that hydrolyze or disrupt massive proteins groups like globulins. Isolated BP can imply high production costs and difficulties on their incorporation into new foods. Functional foods with BP obtained during the production process are an excellent alternative, particularly to eliminate an additional enzymatic hydrolysis step (López-Barrios et al., 2014).

Usually, bean flours are not used as food ingredients due to intrinsic antinutritional factors and the low functionality of starch (Rocha-Guzmán et al., 2006), but these problems can be solved pretreating the beans or bean flours. Germination is an alternative to reduce the antinutritional compounds found in raw bean, such as phytic acid, trypsin inhibitors, and alpha-amylase inhibitors (Mendoza-Sánchez et al., 2016). The antioxidant and anti-inflammatory activity of black bean hydrolysates were reported to increase with germination (de Souza Rocha et al., 2015; López-Barrios et al., 2016).

Extrusion is an interesting technology applied to legume flours to modify its functional properties and reduce the antinutritional factors due to the combined effect of shear stress, specific mechanical and thermic energies that transform legumes flours in high-value products at a low cost. Usually, extrusion has been applied exclusively to soybean defatted flours, but in the latest years, this technology has been used to legumes (Rocha-Guzmán et al. 2006). Extrusion can process in a few seconds plenty of bean flours inactivating some antinutritional factors 
within the beans like the trypsin inhibitors and lipoxygenases (Atienzo Lazos et al., 2011). Extrusion enhanced the anti-inflammatory effect of amaranth (Amaranthus hyochondriacus) flour soluble protein hydrolysates (Montoya-Rodríguez et al., 2014a; Montoya-Rodríguez et al., 2014b; Montoya-Rodríguez et al., 2015). Extrusion and germination have already been successfully used to improve common beans nutritional properties and the development of new food products (Kelkar et al., 2012; López et al., 2013; Nyombaire et al., 2011; Simons et al., 2014; Vidal-Valverde et al., 2002). Temperature and pressure affect protein bioaccessibility and therefore have a significant effect on the release of bioactive peptides (Garcia-Mora et al., 2016). Hence, extrusion conditions could have an impact on the proteins subjected to digestion and generation of bioactive peptides.

It is imperative to point out that bioactive peptides must retain or enhance their beneficial effect on health after digestion to be used as a functional food ingredient (García-Mora et al., 2017). Therefore, the aim of this research was to evaluate the effect of thermoplastic extrusion on the antioxidant and anti-inflammatory activities of the soluble protein from germinated black bean cotyledons and the changes after simulated gastrointestinal digestion.

\section{Materials and Methods}

\subsection{Chemicals}

Germinated cotyledon black bean was produced according to Guajardo-Flores et al. (2016). Solutions like $1 \mathrm{M}$ $\mathrm{HCl}, 0.9 \mathrm{M} \mathrm{NaHCO}_{3}, 1 \mathrm{M} \mathrm{NaOH}$ were from DEQ (Monterrey, México). Pepsin from porcine gastric mucose (P7000), pancreatin from porcine pancreas (P7545), trolox standard, fluorescein, 2,2'azobis (2-amidinopropane) dihydrochloride (AAPH) and BSA were pushing from Sigma-Aldrich, St. Louis, MO, USA. Electrophoresis buffers, reagents, Mini-protean Tetra Cell, molecular weight marker and, sample buffer were purchased from BioRad Laboratories Inc. (Hercules, CA, USA). Human (Homo sapiens) colon epithelial adenocarcinoma cells, Caco-2 and mouse (Mus musculus) macrophage cell line RAW 264.7 were from ATCC, Manassas, VA, USA. DMEM medium, fetal bovine serum, PBS (phosphate buffer solution), and penicillin/streptomycin were purchased from GIBCO (Grand Island, NY, USA); while dichlorofluorescein diacetate (DCFH-DA) and lipopolysaccharide (LPS) from Sigma-Aldrich (St. Louis, MO, USA). Griess reagent system kit G2930 was obtained from Promega (Madison, WI, USA) and high performance chromatography (HPLC) grade water, trifluoroacetic acid and acetonitrile from CTR Scientific (Monterrey, México).

Black beans (Phaseolus vulgaris) var. San Luis was obtained from INIFAP Nicolás Bravo, Durango, México. Germination was carried on according to Guajardo-Flores et al., (2012), in a dark chamber at $24^{\circ} \mathrm{C}$ and constant distilled water nebulization. After $24 \mathrm{~h}$, black beans were dried in a convection oven (Electrolux EOG Gas single oven X 601, Stockholm, Sweden) at $60{ }^{\circ} \mathrm{C}$ for $4 \mathrm{~h}$. Beans were dehulled in a decorticator (Nutana Machine, Saskatoon, SK, Canada) equipped with a set of five $30 \mathrm{~cm}$ diameter carborundum (60 grit) disks. Cotyledons were then separated from coats with a $4 \mathrm{~mm}$ mesh, and finally, cotyledons were ground in a knife mill (Wiley Mill@, Swedesboro, NJ, USA) to pass a $1 \mathrm{~mm}$ screen.

\subsection{Extrudate Production}

A twin-screw co-rotating extruder (BCTM-30, Bühler AG, Uzwil, Switzerland), with a shaft of $800 \mathrm{~mm}$ total length and a ratio $\mathrm{L} / \mathrm{D}=20$ was used. The barrel of the extruder was composed of five blocks, and the last block was preheated at $90^{\circ} \mathrm{C}$ by a heat exchanger device (Tool Temp, Bühler AG, Uzwil, Switzerland). Cotyledons flour was placed on the solids feeder and water on the liquid feeder; fluxes were set at $24.7 \mathrm{~kg} / \mathrm{h}$ and $4.0 \mathrm{~kg} / \mathrm{h}$ respectively. A die with a single circular $4 \mathrm{~mm}$ hole was used. Two different screws speeds, 350 and $400 \mathrm{rpm}$, were used and in consequence, the temperature in the last zone of the barrel was $135^{\circ} \mathrm{C}$ and $149{ }^{\circ} \mathrm{C}$, respectively. Round extrudates was obtain setting cutter at $600 \mathrm{rpm}$ using three knives. The expanded products with expansion index of 4.42 were dried in a convection oven (Electrolux EOG Gas single oven X 601, Stockholm, Sweden) at $100{ }^{\circ} \mathrm{C}$ per 8 min.

\subsection{Enzymatic Digestion and Soluble Protein Quantification}

Extrudates were ground in a coffee mill (Krops GX 4100 México) before protein hydrolysis according to Lo and Li-Chan (2005). Extrudates flour was suspended in distilled water $(1: 20 \mathrm{w} / \mathrm{v})$ containing $0.02 \%$ sodium azide, $\mathrm{pH}$ was adjusted to 2.0 with $1 \mathrm{M} \mathrm{HCl}$, and then pepsin from porcine gastric mucosa was added $(1: 20 \mathrm{w} / \mathrm{w}$ protein basis). The solution was incubated for $1 \mathrm{~h}$ under agitation $(250 \mathrm{rpm})$ at $37^{\circ} \mathrm{C}$, and the $\mathrm{pH}$ was adjusted to 5.3 with $0.9 \mathrm{M} \mathrm{NaHCO}_{3}$ to add pancreatin from porcine pancreas (1:20 w/w protein basis). $\mathrm{pH}$ was adjusted again to 7.5 with $1 \mathrm{M} \mathrm{NaOH}$, and the suspension was incubated for $180 \mathrm{~min}$ under agitation at $37^{\circ} \mathrm{C}$. Aliquots of hydrolysates suspensions were collected during digestion at 0,60, 90, 120 and, $180 \mathrm{~min}$. Samples were 
submerged in boiling water for $10 \mathrm{~min}$ to stop the digestion. After cooling, hydrolysates were neutralized, clarified by centrifugation at $10,000 \mathrm{~g}$ for $15 \mathrm{~min}$ and frozen $\left(-20^{\circ} \mathrm{C}\right)$. A bicinchoninic acid assay (BCA) assay determined the soluble protein content of hydrolysates. Briefly, samples were diluted 1:4 and $20 \mu \mathrm{L}$ of each hydrolysate reacted with $200 \mu \mathrm{L}$ of BCA reactive in a 96 well microplate, along with a BSA calibration curve $(0-10 \mathrm{mg} / \mathrm{mL})$. After $20 \mathrm{~min}$, absorbance at $562 \mathrm{~nm}$ was recorded in a microplate reader (Bio-Tek Instruments Inc., Winooski, VT, USA) with KC4 v3.4 software.

\subsection{Electrophoresis}

SDS-PAGE electrophoresis of samples was executed using a Mini-Protean Tetra Cell. Gels consisted of a 10\% polyacrylamide resolving gel ( $\mathrm{pH} \mathrm{8.8)} \mathrm{and} \mathrm{a} \mathrm{5 \%} \mathrm{stacking} \mathrm{gel} \mathrm{(pH} \mathrm{6.8).} \mathrm{Samples} \mathrm{were} \mathrm{dissolved} \mathrm{in} 2 \mathrm{X}$ Laemmli sample buffer and $15 \mu$ l loaded onto gels $(26 \mu \mathrm{g}$ protein/well based on the soluble protein concentration determined by BSA assay), including a molecular weight marker (Precision Plus Protein Kaleidoscope). After running at $200 \mathrm{~V}, 10 \mathrm{~mA}, 3.0 \mathrm{~W}$, gels were stained with silver according to the Chevallet et al. (2006) protocol.

\subsection{Cellular Antioxidant Activity}

The optimized method by Wan, Liu, Yu, Sun, and Li (2015) with Caco-2 cells was used to assess cellular antioxidant activity (CAA) of protein hydrolysates. Cells were seeded in a black 96 -well plate $\left(100 \mu \mathrm{L}\right.$ at $1 \times 10^{5}$ cells/well), with Dulbecco's modified Eagle's medium (DMEM) medium supplemented with $5 \%$ fetal bovine serum, and maintained at $37{ }^{\circ} \mathrm{C}$ in a humidified $5 \% \mathrm{CO}_{2}$ incubator. After $24 \mathrm{~h}$, cells were washed with PBS (phosphate buffer solution) and incubated for $20 \mathrm{~min}$ with $100 \mu \mathrm{L}$ of hydrolysates at $0.01 \mathrm{mg} / \mathrm{mL}$ of soluble protein and $60 \mu \mathrm{M}$ of dichlorofluorescein diacetate (DCFH-DA). After rewashing the cells, $100 \mu \mathrm{L}$ of 2,2'-Azobis(2-methylpropionamidine) dihydrochloride (AAPH) $(100 \mathrm{mM})$ was added to induce oxidative stress, and fluorescence emitted at $538 \mathrm{~nm}$ with excitation at $485 \mathrm{~nm}$ was measured every 2 min for $120 \min$ at $37^{\circ} \mathrm{C}$. CAA was calculated as a percentage using the following formula:

$$
C A A=100-\left(\frac{\text { NET AUC sample }}{\text { NET AUC positive control }}\right) \times 100
$$

Positive control was cells incubated with dichloro-dihydro-fluorescein diacetate (DCFH-DA) (wit out hydrolysates) and induced with AAPH.

\subsection{Nitric Oxide Inhibitory Activity}

Nitric oxide (NO) inhibitory activity was measured as an indirect effect of anti-inflammatory activity. NO production induced by lipopolysaccharide (LPS) in mouse macrophage cell line RAW 264.7 (ATCC, Manassas, VA, USA) was used. Cells were cultured in 96 -well plates $\left(50 \mu \mathrm{L}, 1 \times 10^{5}\right.$ cells/well) with $100 \mu \mathrm{L}$ of DMEM medium containing $10 \%$ fetal bovine serum, $1 \%$ penicillin/streptomycin (GIBCO Grand Island, NY, USA), and incubated at $37^{\circ} \mathrm{C}$ in $5 \% \mathrm{CO}_{2}$. After $4 \mathrm{~h}$, hydrolysates were added to cells $(50 \mu \mathrm{L} /$ well at $0.04 \mathrm{mg} / \mathrm{mL})$ and left 24 $\mathrm{h}$ in incubation. Cells were activated with LPS $(50 \mu \mathrm{L}, 10 \mu \mathrm{g} / \mathrm{mL})$ during $24 \mathrm{~h}$. For nitrite determination, $100 \mu \mathrm{L}$ of supernatant from each well was transferred to a new plate, and the assay was made according to Griess reagent system kit (Promega, Madison, WI, USA). The original plate where cells remained was used to evaluate cell viability. Cell titer 96 aqueous one solution cell proliferation assay (Promega, Madison, WI, USA) was used. Briefly, $20 \mu \mathrm{L}$ of cell titer reagent was added to each well and cells were incubated for $45 \min \left(37^{\circ} \mathrm{C}\right.$ in the dark). Absorbance at $490 \mathrm{~nm}$ was measured in microplate reader (Bio-Tek Instruments Inc., Winooski, VT, USA). The NO production was esteemed as percentage considering cells with LPS stimuli and no treatment as $100 \%$. Mouse macrophage cell line was acquired from American Type Culture Collection (ATCC, Manassas, VA, USA).

\subsection{HPLC-MS-TOF Analysis}

Hydrolysates were analyzed by HPLC-MS-TOF (Model G1969A Agilent 1100, Santa Clara, CA, USA) as previously reported (Torres-Fuentes et al., 2015). Samples adjusted to a concentration of $0.15 \mathrm{mg} / \mathrm{mL}$ were injected into a XBridge BEH300 $\mathrm{C}_{18}$ column $(250 \times 4.6 \mathrm{~mm}, 5 \mu \mathrm{m}$ of particle size, Waters Corporation, Milford, MA, USA), injection volume was $5 \mu \mathrm{L}$. Solvent A consisted of HPLC grade water with trifluoroacetic acid (TFA, 1000:0.37, v/v) and solvent B was acetonitrile and TFA (1000:0.27, v/v). Elution was conducted with a linear gradient of solvent B in A from $0 \%$ to $70 \%$ over $90 \mathrm{~min}$, at a flow rate of $0.75 \mathrm{~mL} / \mathrm{min}$.

Positive ions were recorded over the mass/charge $(\mathrm{m} / \mathrm{z})$ range of 100-2800. Nitrogen was used as nebulizing and drying gas $\left(35 \mathrm{psi}, 12 \mathrm{~L} / \mathrm{min}, 350^{\circ} \mathrm{C}\right)$. The capillary was held at $3 \mathrm{kV}$, and fragment voltage at $225 \mathrm{~V}$. Total ion chromatogram (TIC) of germinated cotyledon was subtracted from TIC of germinated cotyledons extrudates to obtain the accurate mass of peptides produced by the extrusion process. On the other hand, TIC from undigested extrudates was subtracted from TIC of extrudates hydrolysates achieved after $180 \mathrm{~min}$ to obtain the accurate 
mass of peptides produced by digestion. Mass spectra were extracted with MassHunter workstation software (Agilent Technologies, Santa Clara, CA, USA). Peptides were identified using MASCOT Peptide Mass Fingerprint server with the following parameters: SwissProt and NCBInr database, peptide tolerance 1.2 Da, no enzyme and variable modification, taxonomy Viridiplantae. Sequences identified from Phaseolus vulgaris were searched in Biopep database for their potential biological activity.

\subsection{Statistics}

Results were expressed as mean \pm standard error; all results are derived from at least 3 replicates. The software JMP 11.2.0 (SAS Institute Inc., Cary, NC, USA) was used to determine significant differences by ANOVA and Tukey test to compare treatments with a significance level of $\alpha=0.05(\mathrm{p} \leq 0.05)$.

\section{Results and Discussions}

\subsection{Soluble Protein Profile and of Germinated Extruded Cotyledon Black Bean}

The SDS-PAGE patterns showed the difference in protein size due to extrusion treatment (E1 and E2) and time of enzymatic treatment (Figure 1A). Before enzymatic digestion, germinated cotyledons extrudates (E1 and E2) presented a strong signal around $25 \mathrm{kDa}$, which according to bibliography corresponds to the protein phytohemagglutinin (Figure 1A) (Garcia-Mora et al., 2016). The irregular definition of the $25 \mathrm{kDa}$ signal also indicates contamination with protein fragments produced during extrusion, as it was observed in previous reports using high temperature or pressure (Garcia-Mora et al., 2016; Mojica \& de Mejía, 2015). Particularly for E2, the band around $25 \mathrm{kDa}$ was more intense and irregular than the observed in E1 because of screw speed, specific mechanical energy (SME) and temperature were more intense for the E2 treatment compared with E1. Alonso et al. (2001) studied the nutritional effect of extrusion of P. sativum L. cv Ballet and P. vulgaris L. var. Pinto with in vivo assay. The extrusion was carried out at 150 and $155^{\circ} \mathrm{C}$. They prove the enhanced bioavailability of mineral nutrients without changes in the chemical composition between raw material and extrudates. They demonstrated the destruction of antinutritional factors as phytates due to extrusion temperature. Batista and collaborators (2010) extruded common beans (Phaseolus vulgaris, L.) at $150{ }^{\circ} \mathrm{C}$ decreasing antinutrients factors as phytic acid, lectin, $\alpha$-amylase, and trypsin inhibitors, enhancing the starch and protein in vitro digestibilities. In this research similar conditions were use. The reduction of protein bean molecular weight indicates the effect of temperature and shear stress inside the extruder barrel, leading to the reduction of antinutritional factors and enhancing the protein digestibility as the referenced works.

Also, before enzymatic digestion, an unidentified band around $85 \mathrm{kDa}$ was present only in E1. This band remained in the 60 min enzymatic hydrolysate but at a much lower intensity and finally disappeared at 90 min. Small fragments of protein $(<15 \mathrm{kDa})$ were most noticeable in E1, even before enzymatic hydrolysis, due to the higher temperature generated during extrusion. Furthermore, those small bands increased their intensity and definition after 90 min of enzymatic digestion as consequence of the generation of small peptides, as it has been reported for extruded amaranth (Montoya-Rodríguez et al., 2015). Extrusion did not eliminate proteins as previously suggested (Kelkar et al., 2012). Extrusion affected the solubility of germinated cotyledons proteins due to their aggregation or interactions with non-protein macromolecules (Chen, Wei, \& Zhang, 2011, Garcia-Mora et al., 2016). During enzymatic digestion of the extrudates, the protein aggregation was reduced, and therefore proteins were solubilized (Figure 2B). Hence, 60 or $90 \mathrm{~min}$ of enzymatic digestion were required to observe the characteristic bands from phaseolin subunits ( 40 and $53 \mathrm{kDa})$ and legumin $(70 \mathrm{kDa})$ for E1 or E2, respectively (Figure 2A). In both extrudates, as enzymatic digestion continued, these protein bands lost their intensity as an indicator of the improvement of protein digestion due to extrusion. The extrusion temperature denatured the protein structure; nevertheless, the SME (the mainly result of shear stress) is the most critical variable that affects the denaturation and disruption of proteins (Riaz, 2000). 

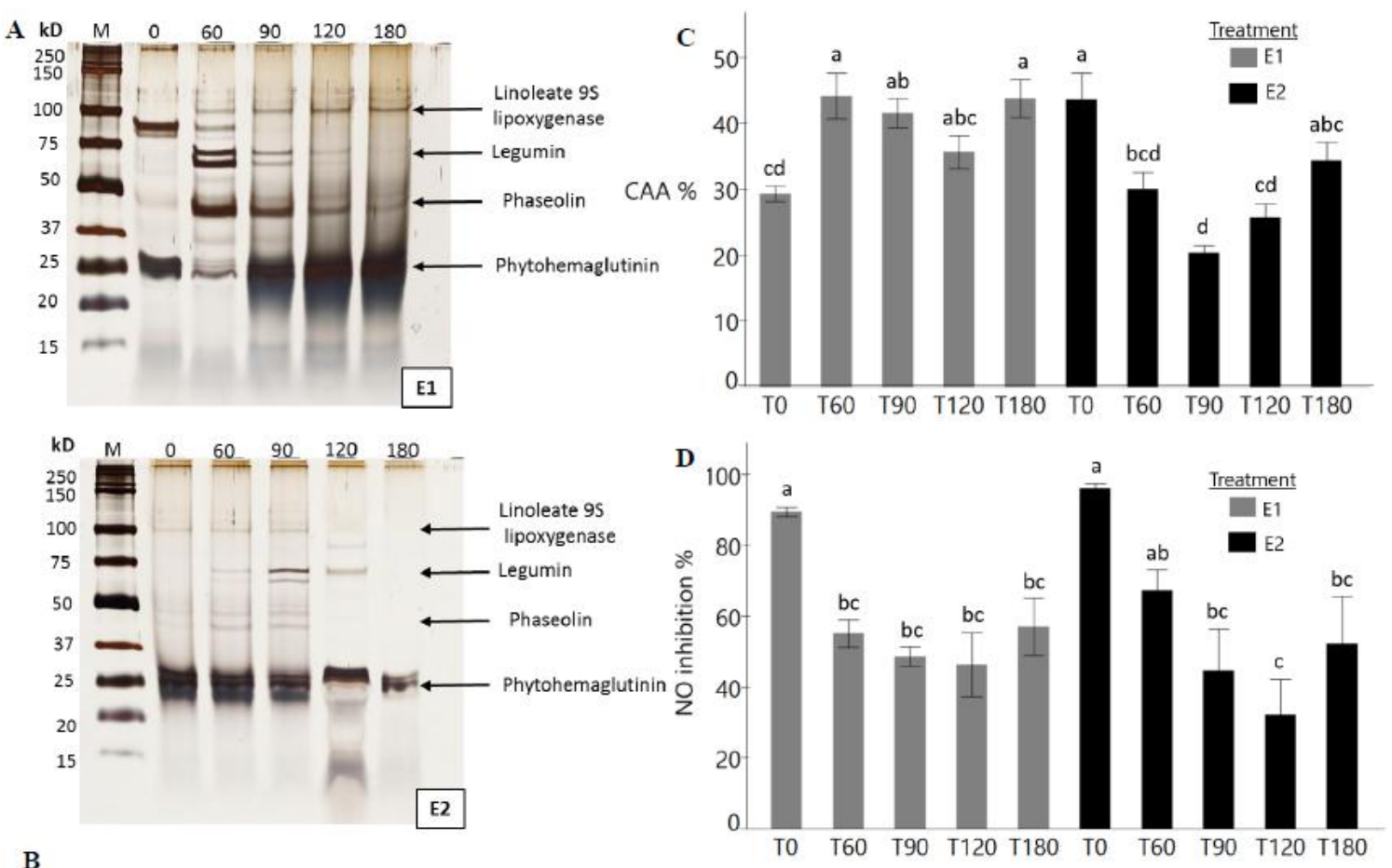

B

\begin{tabular}{|c|c|c|c|c|c|}
\hline & \multicolumn{5}{|c|}{ Digestion time (min) } \\
\hline & 0 & 60 & 90 & 120 & 180 \\
\hline Extrudate sample & \multicolumn{5}{|c|}{ mg of soluble protein/g of extrudate } \\
\hline E1 & $6.8 \pm 3.4 c$ & $25.3 \pm 4.6 b c$ & $33.1 \pm 4.9 \mathrm{ab}$ & $45.8 \pm 6.5 \mathrm{ab}$ & $55.2 \pm 9.6 a$ \\
\hline E2 & $7.9 \pm 0.9 b$ & $36.3 \pm 7.9 \mathrm{ab}$ & $65.8 \pm 4.4 \mathrm{a}$ & $43.6 \pm 9.3 \mathrm{ab}$ & $49.2 \pm 10.7 \mathrm{ab}$ \\
\hline
\end{tabular}

Figure 1. Protein profile (A), soluble protein content (B), antioxidant activity (C), and anti-inflammatory activity (D) of soluble protein hydrolysates (0-180 min) from germinated cotyledons extrudates obtained at $350 \mathrm{rpm}$ (E1) and $400 \mathrm{rpm}$ (E2). Treatment comparisons were made and different letters ${ }^{\mathrm{a}}$ ) indicate significant differences among hydrolysates of the same extrudate $(\alpha<0.05)$. T0, T60, T90, T120 and T180 refer to hydrolysis time at 0 , $60,90,120$ and $180 \mathrm{~min}$, respectively

\subsection{Cellular Antioxidant Activity}

The AOX compounds must get inside the Caco-2 cells to exert their activity, and therefore membrane permeability is determinant to the compounds assayed (Wan et al., 2015). In consequence, bioactive compounds can have different activity in both chemical and cells assays. When tested at $0.01 \mathrm{mg} / \mathrm{mL}$, E2 without enzymatic digestion presented higher CAA compared to E1 (Figure 1C), probably due to the intensity of the unidentified signal of around $85 \mathrm{kDa}$ observed in the electrophoretic profile (Figure 1A).

In a cellular environment, peptides with lower molecular weight have stronger ability to scavenge free radicals than large molecules (Shi, Kovacs-Nolan, Jiang, Tsao, \& Mine, 2014). Enzymatic digestion of E1 increased the content of small peptides as it can be noticed in the electrophoretic profile (Figure 1A), which in turn was reflected in the cellular antioxidant activity (Figure 1C).

The different case occurred with E2, which decreased its cellular antioxidant activity with enzymatic digestion, from 60 to $120 \mathrm{~min}$. E2 hydrolyzed $90 \mathrm{~min}$ presented a particular decrease in AOX activity in CAA assays. This hydrolysate showed the most intense legumin band (Figure 1A). Interestingly, previous reports indicate that legumin must be converted into peptides to increase the AOX capacity (Garcia-Mora et al., 2014). AOX capacity increased in the hydrolysates digested for 120 and $180 \mathrm{~min}$.

\subsection{NO Inhibitory Activity}

E1 and E2 exhibited the highest NO inhibitory activity before enzymatic digestion, being 89.5 and $96.1 \%$ respectively (Figure 1D). As observed with amaranth, extrusion improved the anti-inflammatory activity tested in macrophages (Montoya-Rodríguez et al., 2014a). After 60 min digestion, only E1 hydrolysates reduced their 
NO inhibitory activity to $55.2 \%$. Protein profile of E2 at $60 \mathrm{~min}$ of enzymatic digestion was very similar, as well as their anti-inflammatory activities. By $90 \mathrm{~min}$ of E2 enzymatic digestion, legumin and phaseolin regained solubility, and the anti-inflammatory activity was reduced. Therefore, peptides generated by the extrusion process (E2 T0) were at higher concentrations and conferring higher activity before legumin regained solubility. Enzymatic digestion of legumin produced bioactive peptides as it can be noticed on the increase of activity at 180 min that did not reach the NO inhibition observed for E2 T0. Rocha et al. (2014) shown the enhanced effect of AOX capacity of germination and the adverse effect of enzymatic digestion over the AOX capacity. The addition of alcalase in the germinated cowpea beans did not increase the AOX capacity, but the hydrolysis with alcalase of regular cowpea bean generated a good AOX capacity. Despite the decreased activity of E1 and E2 when digested, extrusion improved the anti-inflammatory activity of germinated cotyledon previously reported (López-Barrios et al., 2016).

\subsection{Qualitative Characterization of Hydrolysates by HPLC-MS-TOF}

Protein hydrolysates were analyzed, and the HPLC-MS-TOF profiles are shown in Fig. 2. To approximate the identity of the peptides generated by the extrusion (E1 and E2) of germinated black bean cotyledons, the signal from unextruded total ion chromatogram (TIC) was subtracted from their TIC. In E2 there were more peptide signals than in E1 confirming that extrusion conditions affected the release of peptides. Besides small $\mathrm{m} / \mathrm{z}$ signals, ions of $\mathrm{m} / \mathrm{z} 705$ and 543 were found in both extrudates samples (Table 1). Additionally, un-extruded germinated cotyledon also presented an $\mathrm{m} / \mathrm{z}$ signal at 705 , but the difference in the mass spectrum indicates that it was not the same peptide than the one detected in E1 and E2.

Amino acid sequences from $P$. vulgaris peptides with molecular weight of $704 \mathrm{Da}$ were obtained from databases, but none has been previously reported with biological activity. In contrast, the peptides related to $\mathrm{m} / \mathrm{z}$ of 689 or 543 were found in Biopep database as P. vulgaris peptides with angiotensin converting enzyme (ACE) inhibitor and AOX activity or dipeptidyl peptidase IV (DPP IV) inhibitory activity, respectively (Table 1). The results of the weight of bioactive peptides match with those obtained for Rocha et al., (2014), detecting a variety of peptides from 259.2 to $2010.0 \mathrm{Da}$.
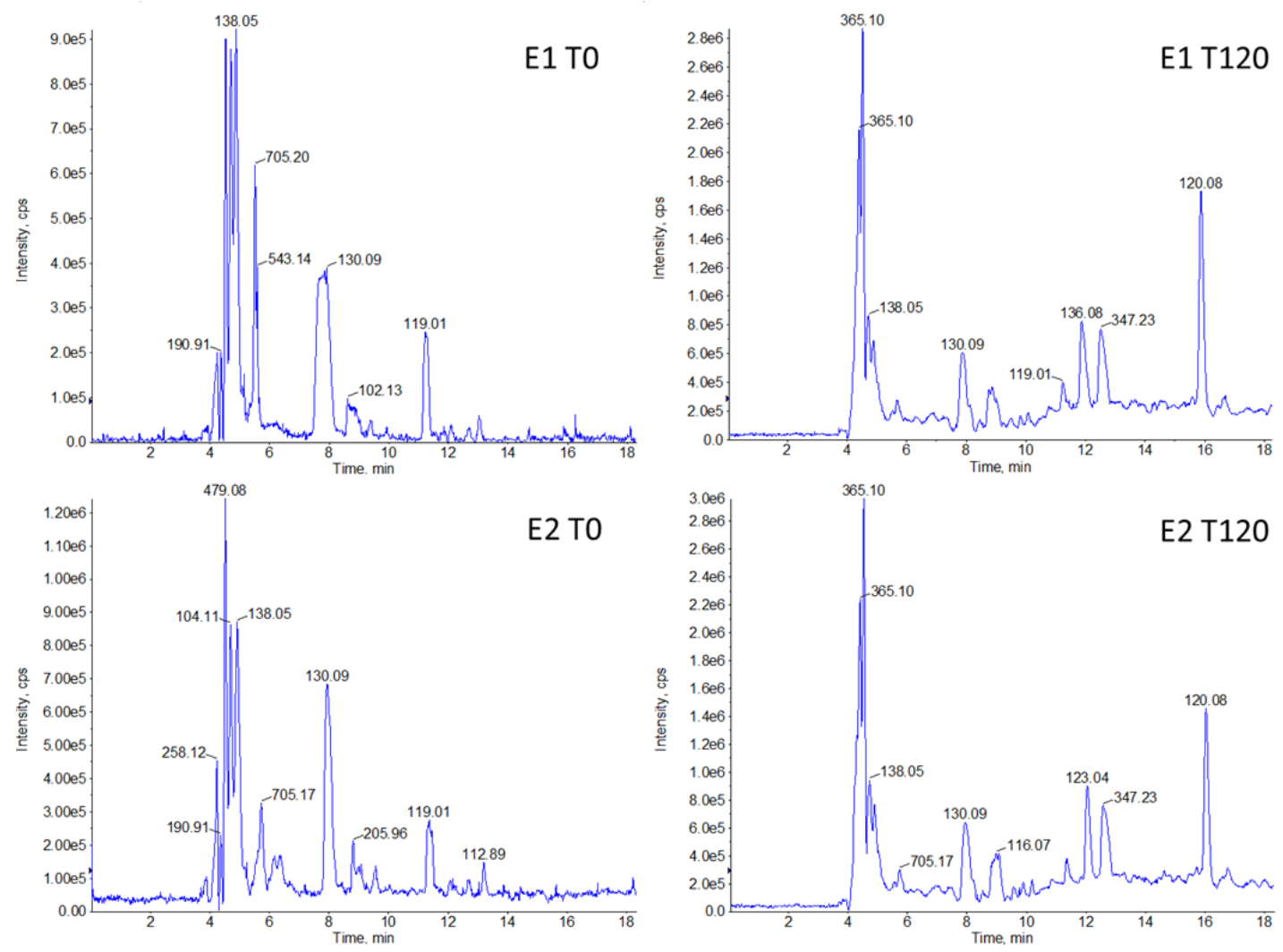

Figure 2. Total ion chromatogram of extrudated germinated cotyledons at $39^{\circ} \mathrm{C}(\mathrm{E} 1 \mathrm{~T} 0), 145^{\circ} \mathrm{C}(\mathrm{E} 2 \mathrm{~T} 0)$ and their 120 min hydrolysates (E1 T120, E2 T120) 
On the other hand, the differences between the TIC of extrudates and their correspondent 120 min hydrolysates demonstrate that extrusion generated different peptides than those obtained after enzymatic digestion (Figure 1). Interestingly, TIC from E1 and E2 digested 120 min were very similar. Even though extrudates presented different peptides profiles as consequence of the extrusion process, the enzymatic digestion of the storage proteins released similar peptides.

TIC of extrudates were subtracted to each of their hydrolysates to approximate the identity of peptides generated by enzymatic digestion. Overall, E1 presented more peptide signals and increased with hydrolysis time (data not shown). Among the identified peptides obtained after $180 \mathrm{~min}$ of enzymatic digestion, RLL and YAL have been previously described as part of bioactive peptides (Table 1). YAL belongs to a peptide sequence with ACE inhibitory activity from marine products waste (Wako et al., 1996). RLL was found in two peptides from precooked and digested $P$. vulgaris, with ACE and DPP IV inhibitory activities (Mojica et al., 2015).

Table 1. Peptide sequences identified according the differential $\mathrm{m} / \mathrm{z}$ signal between un-extruded and extruded germinated cotyledons

\begin{tabular}{|c|c|c|c|c|c|c|c|}
\hline$m / z$ & $\begin{array}{l}\text { Mass in } \\
\text { E1 }\end{array}$ & $\begin{array}{l}\text { Mass in } \\
\text { E2 }\end{array}$ & $\begin{array}{l}\text { Mass } \\
\text { (calc.) }\end{array}$ & Sequence & Enzyme / Database & $\begin{array}{l}\text { Biological } \\
\text { activities }\end{array}$ & P. vulgaris source protein \\
\hline \multirow[t]{7}{*}{705} & 704.20 & 704.17 & 703.39 & CEVIIK & Trypsin / NCBInr & $\mathrm{NF}$ & Hypothetical \\
\hline & & & & & & & PHAVU_004G1381001g \\
\hline & & & 705.34 & GGSSDKR & TrypChymo / SwissProt & $\mathrm{NF}$ & Wound-induced basic protein \\
\hline & & & 704.42 & FQIGKL & Chymotrypsin / NCBInr & $\mathrm{NF}$ & Hypothetical \\
\hline & & & & & & & PHAVU_011G1771001g \\
\hline & & & 703.28 & PHGCQY & Pepsin / NCBInr & $\mathrm{NF}$ & Hypothetical \\
\hline & & & & & & & PHAVU_002G2817001g \\
\hline \multirow[t]{6}{*}{479} & NP & 478.08 & 477.28 & RFR & Trypsin / SwissProt & $\mathrm{NF}$ & Chloroplast inner envelope \\
\hline & & & & & & & protein \\
\hline & & & 477.17 & SEEN & Trypsin / NCBInr & $\mathrm{NF}$ & Hypothetical \\
\hline & & & & & & & PHAVU_009G2231001g \\
\hline & & & 478.28 & VYVV & Trypsin / NCBInr & $\mathrm{NF}$ & Hypothetical \\
\hline & & & & & & & PHAVU_006G1949001g \\
\hline \multirow[t]{3}{*}{689} & NP & 689.19 & 688.77 & RWAEK & BIOPEP & ACE inhibitor & Hypothetical \\
\hline & & & & & & and AOX & PHAVU_005G180600g \\
\hline & & & 688.35 & LDRGQT & Trypsin / SwissProt & $\mathrm{NF}$ & Thaumatin-like protein \\
\hline \multirow[t]{2}{*}{543} & 542.14 & 542.14 & 542.62 & WIQP & BIOPEP & DPP IV inhibitor & Hypothetical \\
\hline & & & & & & & PHAVU_L009200g \\
\hline \multirow[t]{2}{*}{365} & 365.1 & 365.1 & 365.19 & YAL & Chymotrypsin, pepsin, & Part of ACE & \multirow{2}{*}{$35 \mathrm{kDa}$ cell wall protein } \\
\hline & & & & & Trypsin / SwissProt & inhibitor peptides & \\
\hline \multirow[t]{2}{*}{400} & 400.25 & NP & 400.27 & RLL & Pepsin / NCBInr & $\mathrm{NF}$ & Hypothetical \\
\hline & & & & & & & PHAVU_009G0280000g \\
\hline
\end{tabular}

E1, extrudate generated at $350 \mathrm{rpm}$; E2, extrudate generated at $400 \mathrm{rpm}$; NP, Not present; NF, Not found

ACE inhibitor, angiotensin converting enzyme inhibitory activity (related to hypertension); AOX, antioxidant activity; DPP IV inhibitor, dipeptidyl peptidase IV inhibiting activity (related to antidiabetic activity)

\section{Conclusions}

Extrusion of germinated black bean cotyledons improved the release of bioactive peptides with antioxidant and anti-inflammatory activities. Peptides generated by the extrusion process without enzymatic treatment were at higher concentrations and conferring higher cellular antioxidant activity. Protein aggregates generated by extrusion affected the release of proteins that do not have AOX activity before being digested, this was particularly observed for legumin. Even though extrudates presented different peptides profiles, the enzymatic 
digestion of the storage proteins released similar peptides. Extrusion of germinated black bean cotyledons can be a useful process to produce novel functional ingredients from legume proteins for the food industry.

\section{Acknowledgements}

This research was supported by the NutriOmics Research Chair Funds from Tecnologico de Monterrey and Nutrigenomics Research Chair Funds from Fundación FEMSA. The scholarship of Lidia López Barrios (CVU-295031) was provided by Consejo Nacional de Ciencia y Tecnología (CONACYT) and Tecnológico de Monterrey. Irasema Romo-López, Liliana Santos-Zea and Jesús Hernández also contributed to this project with their laboratory skills.

\section{References}

Alonso R., Rubio L. A., Muzquiz M., \& Marzo F. (2001). The effect of extrusion cooking on mineral bioavailability in pea and kidney bean seed meals. Animal Feed Science and Technology, 94, 1-13.

Atienzo L, M., Delgado, E., Ochoa-Martínez, A., Aguilar Palazuelos, E., Martínez, B. F., Ramirez-Wong, B., Gallegos Infante, A., Medrano-Roldan, H., \& Solis-Soto. A. (2011). Effect of moisture and temperature on the functional properties of composite flour extrudates from beans (Phaseolus vulgaris) and nixtamalized corn (Zea mays). Journal of Animal Production Advances, 1(1), 9-20.

Batista A. K., Prudêncio S. H., \& Fernandes K. F. (2010). Changes in the functional properties and antinutritional factors of extruded hard-to-cook common beans (Phaseolus vulgaris, L.). Journal of Food Science, 75(3), 286-290.

Chen, F. L., Wei, Y. M., \& Zhang, B. (2011). Chemical cross-linking and molecular aggregation of soybean protein during extrusion cooking at low and high moisture content. LWT-Food Science and Technology, 44, 957-962. https://doi.org/10.1016/j.lwt.2010.12.008

Chevallet, M., Luche, S., \& Rabilloud, T. (2006). Silver staining of proteins in polyacrylamide gels. Nature Protocols, 1, 1852-1858. https://doi.org/10.1038/nprot.2006.288

Garcia-Mora, P., Peñas, E., Frias, J., \& Martínez-Villaluenga, C. (2014). Savinase, the most suitable enzyme for releasing peptides from lentil (Lens culinaris var. Castellana) protein concentrates with multifunctional properties. Journal of Agricultural and Food Chemistry, 62, 4166-4174. https://doi.org/10.1021/jf500849u

Garcia-Mora, P., Peñas, E., Frias, J., Zielinski, H., Wiczkowski, W., Zielinska, D., \& Martinez-Villaluenga, C. (2016). High pressure-assisted enzymatic release of peptides and phenolics increase angiotensin converting enzyme I inhibitory and antioxidant activities of pinto bean hydrolysates. Journal of Agricultural and Food Chemistry, 64, 1730-1740. https://doi.org/10.1021/acs.jafc.5b06080

García-Mora, P., Martín-Martínez, M., Bonache, M. A., González-Múniz, R., Peñas, E., Frias, J., \& Martínez-Villaluenga, C. (2017). Identification, functional gastrointestinal stability and molecular docking studies of lentil peptides with dual antioxidant and angiotensin I converting enzyme inhibitory activities. Food Chemistry, 221, 464-472. https://doi.org/10.1016/j.foodchem.2016.10.087

Ghavidel, R. A., \& Prakash, J. (2007). The impact of germination and dehulling on nutrients, antinutrients, in vitro iron and calcium bioavailability and in vitro starch and protein digestibility of some legume seeds. LWT-Food Science and Technology, 40, 1292-1299. https://doi.org/10.1016/j.lwt.2006.08.002

Guajardo-Flores D., García-Patiño M., Serna-Guerrero D., Gutiérrez-Uribe, J. A., \& Serna-Saldívar, S. O. (2012). Characterization and quantification of saponins and flavonoids in sprouts, seed coats and cotyledons of germinated black beans. Food Chemistry, 134, 1312-1319. https://doi.org/10.1016/j.foodchem.2012.03.020

Iqbal, A., Khalil, I. A., Ateeq, N., \& Khan, M. S. (2006). Nutritional quality of important food legumes. Food Chemistry, 97, 331-335.

Kelkar, S., Siddiq, M., Harte, J. B., Dolan, K. D., Nyombaire, G., \& Suniaga, H. (2012). Use of low-temperature extrusion for reducing phytohemagglutinin activity (PHA) and oligosaccharides in beans (Phaseolus vulgaris L.) cv. Navy and Pinto. Food Chemistry, 133, 1636-1639. https://doi.org/10.1016/j.foodchem.2012.02.044

Lo, W. M. Y., \& Li-Chan, E. C. Y. (2005). Angiotensin I converting enzyme inhibitory peptides from in vitro pepsin-pancreatin digestion of soy protein. Journal of Agricultural and Food Chemistry, 53, 3369-76. https://doi.org/10.1021/jf048174d

López, A., El-Naggar, T., Dueñas, M., Ortega, T., Estrella, I., Hernández, T., Gómez-Serranillos, M. P., Palomino, O. M., \& Carretero, M. E. (2013). Effect of cooking and germination on phenolic composition and 
biological properties of dark beans (Phaseolus vulgaris L.). Food Chemistry, 138, 547-55. https://doi.org/10.1016/j.foodchem.2012.10.107

López-Barrios, L., Antunes-Ricardo, M., \& Gutiérrez-Uribe, J. A. (2016). Changes in antioxidant and antiinflammatory activity of black bean (Phaseolus vulgaris L.) protein isolates due to germination and enzymatic digestion. Food Chemistry, 203, 417-424. https://doi.org/10.1016/j.foodchem.2016.02.048

López-Barrios, L., Gutiérrez-Uribe, J. A., \& Serna-Saldívar, S. O. (2014). Bioactive peptides and hydrolysates from pulses and their potential use as functional ingredients. Journal of Food Science, 79, R273-R283. https://doi.org/10.1111/1750-3841.12365

Luna-Vital, D. A., Mojica, L., González de Mejía, E., Mendoza, S., \& Loarca-Piña, G. (2014). Biological potential of protein hydrolysates and peptides from common bean (Phaseolus vulgaris L.): A review. Food Research International, 76, 39-50. https://doi.org/10.1016/j.foodres.2014.11.024

Marques, M. R., Fontanari, G. G., Pimenta, D. C., Soares-Freitas, R. M., \& Arêas, J. A. G. (2015). Proteolytic hydrolysis of cowpea proteins is able to reliease peptides with hypodholesterolemic activity. Food Research International, 77, 43-48.

Mendoza-Sánchez M., Guevara-González R. G., Castaño-Tostado E., Mercado-Silva, E. M., Acosta-Gallegos, J. A., Rocha-Guzmán, N. E., \& Reynoso-Camacho, R. (2016). Effect of chemical stress on germination of cv Dalia bean (Phaseolus vularis L.) as an alternative to increase antioxidant and nutraceutical compounds in sprouts. Food Chemistry, 212, 128-137. https://doi.org/10.1016/j.foodchem.2016.05.110

Mojica, L., \& de Mejía, E. G. (2015). Characterization and comparison of protein and peptide profiles and their biological activities of improved common bean cultivars (Phaseolus vulgaris L.) from Mexico and Brazil. Plant Foods for Human Nutrition, 70, 105-112. https://doi.org/10.1007/s11130-015-0477-6

Mojica, L., Chen, K., \& de Mejía, E. G. (2015). Impact of commercial precooking of common bean (Phaseolus vulgaris) on the generation of peptides, after pepsin-pancreatin hydrolysis, capable to inhibit dipeptidyl peptidase-IV. Journal of Food Science, 80, H188-H198. https://doi.org/10.1111/1750-3841.12726

Montoya-Rodríguez, A., González de Mejía, E., Dia, V. P., Reyes-Moreno, C., \& Milán-Carrillo, J. (2014a). Extrusion improved the anti-inflammatory effect of amaranth (Amaranthus hypochondriacus) hydrolysates in LPS-induced human THP-1 macrophage-like and mouse RAW 264.7 macrophages by preventing activation of NF-KB signaling. Molecular Nutrition and Food Research, 58, 1028-1041. https://doi.org/10.1002/mnfr.201300764

Montoya-Rodríguez, A., Milán-Carrillo, J., Dia, V. P., Reyes-Moreno, C., \& González de Mejía, E. (2014b). Pepsin-pancreatin protein hydrolysates from extruded amaranth inhibit markers of atherosclerosis in LPS-induced THP-1 macrophages-like human cells by reducing expression of proteins in LOX-1 signaling pathway. Proteome Science, 12, 30. https://doi.org/10.1186/1477-5956-12-30

Montoya-Rodríguez, A., Milán-Carrillo, J., Reyes-Moreno, C., \& de Mejía, E. G. (2015). Characterization of peptides found in unprocessed and extruded amaranth (Amaranthus hypochondriacus) pepsin/pancreatin hydrolysates. International Journal of Molecular Sciences, 16, 8536-8554.

https://doi.org/10.3390/ijms16048536

Nyombaire, G., Siddiq, M., \& Dolan, K. D. (2011). Physico-chemical and sensory quality of extruded light red kidney bean (Phaseolus vulgaris L.) porridge. LWT - Food Science and Technology, 44, 1597-1602. https://doi.org/10.1016/j.lwt.2011.02.016

Osen, R., Toelstede, S., Eisner, P., \& Schweiggert-Weisz, U. (2015). Effect of high moisture extrusion cooking on protein-protein interactions of pea (Pisum sativum L.) protein isolates. International Journal of Food Science \& Technology, 50, 1390-1396. http://doi.otg/10.1111/ijfs.12783

Ou, B., Hampsch-Woodill, M., \& Prior, R. L. (2001). Development and validation of an improved oxygen radical absorbance capacity assay using fluorescein as the fluorescent probe. Journal of Agricultural and Food Chemistry, 49, 4619-4626. http://www.ncbi.nlm.nih.gov/pubmed/11599998

Riaz, M. N. (2000). Extruders in food applications. CRC Press, ISBN 9781566767798-CAT \#TX67792, 240 pp.

Rocha-Guzmán, N. E., Gallegos-Infante, J. A., González-Laredo, R. F., Castillo-Antonio, P. A., Delgado-Licon, E., \& Ibarra-Pérez, F. I. (2006). Functional properties of three common Bean (Phaseolus vulgaris) cultivars stored under accelerated conditions followed by extrusion. LWT-Food Science and Technology, 39, 6-10.

Rocha, T. S., Real, L. M. H., Chang, Y. K., \& Gómez, E. de M. (2014). Impact of germination and enzymatic 
hydrolysis of cowpea bean (Vigna unguiculata) on the generation of peptides capable of inhibiting dipeptidyl peptidase IV. Food Research International, 64, 799-809.

https://doi.org/10.1016/j.foodres.2014.08.016

Rocha, T. S., Real, L. M. H., Mojica, L., Johnson, M. H., Chang, Y. K., \& González, E. de M. (2015). Germination of Phaseolus vulgaris and alcalase hydrolysis of its proteins produced bioactive peptides capable of improving markers related to type-2 diabetes in vitro. Food Research International, 76, 150-159. https://doi.org/10.1016/j.foodres.2015.04.04

Shi, Y., Kovacs-Nolan, J., Jiang, B., Tsao, R., \& Mine, Y. (2014). Antioxidant activity of enzymatic hydrolysates from eggshell membrane proteins and its protective capacity in human intestinal epithelial Caco-2 cells. Journal of Functional Foods, 10, 35-45. https://doi.org/10.1016/j.jff.2014.05.004

Simons, C. W., Hall, C., Tulbek, M., Mendis, M., Heck, T., \& Ogunyemi, S. (2014). Acceptability and characterization of extruded pinto, navy and black beans. Journal of the Science of Food and Agriculture, 95, 2287-2291. https://doi.org/10.1002/jsfa.6948

Sosulski, F. W., \& Imafidon, G. I. (1990). Amino acid composition and nitrogen-to-protein conversion factors for animal and plant foods. Journal of Agricultural and Food Chemistry, 38, 1351-1356.

Torres-Fuentes, C., Contreras, M. D. M., Recio, I., Alaiz, M., \& Vioque, J. (2015). Identification and characterization of antioxidant peptides from chickpea protein hydrolysates. Food Chemistry, 180, 194-202. https://doi.org/10.1016/j.foodchem.2015.02.046

Vidal-Valverde, C., Frias, J., Sierra, I., Blazquez, I., Lambein, F., \& Kuo, Y.-H. (2002). New functional legume foods by germination: effect on the nutritive value of beans, lentils and peas. European Food Research and Technology, 215, 472-477. https://doi.org/10.1007/s00217-002-0602-2

Wako, Y., Ishikawa, S., \& Muramoto, K. (1996). Angiotensin I-converting enzyme inhibitors in autolysates of squid liver and mantle muscle. Bioscience, Biotechnology, and Biochemistry, 60, 1353-1355. https://doi.org/10.1271/bbb.60.1353

Wan, H., Liu, D., Yu, X., Sun, H., \& Li, Y. (2015). A Caco-2 cell-based quantitative antioxidant activity assay for antioxidants. Food Chemistry, 175, 601-608. https://doi.org/10.1016/j.foodchem.2014.11.128

\section{Copyrights}

Copyright for this article is retained by the author(s), with first publication rights granted to the journal.

This is an open-access article distributed under the terms and conditions of the Creative Commons Attribution license (http://creativecommons.org/licenses/by/4.0/). 